\title{
Modelling age- and density-related gas exchange of Picea abies canopies in the Fichtelgebirge, Germany
}

\author{
Eva Falge*, John D. Tenhunen, Ron Ryel, Martina Alsheimer and Barbara Köstner
}

Biometeorology, ESPM, Univ. of California, Berkeley, CA 94720, USA

(Received 22 July 1999; accepted 1 December 1999)

\begin{abstract}
Differences in canopy exchange of water and carbon dioxide that occur due to changes in tree structure and density in montane Norway spruce stands of Central Germany were analyzed with a three dimensional microclimate and gas exchange model STANDFLUX. The model was used to calculate forest radiation absorption, the net photosynthesis and transpiration of single trees, and gas exchange of tree canopies. Model parameterizations were derived for six stands of Picea abies (L.) Karst. differing in age from 40 to 140 years and in density from 1680 to 320 trees per hectare. Parameterization included information on leaf area distribution from tree harvests, tree positions and tree sizes. Gas exchange was modelled using a single species-specific set of physiological parameters and assuming no influence of soil water availability. For our humid montane stands, these simplifying assumptions appeared to be acceptable. Comparisons of modelled daily tree transpiration with water use estimates from xylem sapflow measurements provided a test of the model. Estimates for canopy transpiration rate derived from the model and via xylem sapflow measurements agreed within $\pm 20 \%$, especially at moderate to high air vapor pressure deficits. The results suggest that age and density dependent changes in canopy structure (changes in clumping of needles) and their effect on light exposure of the average needle lead to shifts in canopy conductance and determine tree canopy transpiration in these managed montane forests. Modelled canopy net photosynthesis rates are presented, but have not yet been verified at the canopy level.
\end{abstract}

norway spruce / xylem sapflow / canopy transpiration / canopy light use efficiency / biosphere-atmosphere interactions

Résumé - Effet de l’âge et de la densité sur la modélisation des échanges gazeux dans la canopée de peuplements de Picea abies (L) Karst. dans le Fichtelgebirge (Allemagne). Les différences d'échange d'eau et de dioxyde de carbone au niveau de la canopée qui se produisent à la suite de changements dans la structure et la densité des arbres dans des peuplements d'Epicéa commun en zone de montagne de l'Allemagne centrale, ont été analysées selon le modèle tridimensionnel de microclimat et d'échange gazeux STANDFLUX. Le modèle a été utilisé pour calculer l'absorption du rayonnement par la forêt, le bilan photosynthétique net et la transpiration d'arbres individuels, et les échanges gazeux au niveau de la canopée. La paramétrisation du modèle a été effectuée à partir des mesures dans six peuplements de Picea abies (L.) Karst. dont l'âge variait de 40 à 140 ans et la densité des peuplements de 1680 à 320 arbres par hectare. La paramétrisation incluait l'information sur la distribution de la surface foliaire à partir de l'exploitation d'arbres, la position des arbres et leurs dimensions. Les échanges gazeux ont été modélisés en utilisant une série de paramètres physiologiques spécifiques de l'espèce, et en supposant qu'il n'y avait aucune influence de la disponibilité en eau. Pour les peuplements considérés en zone humide de montagne, ces hypothèses semblent acceptables. La comparaison de l'estimation par modélisation de la transpiration journalière avec l'estimation de l'eau absorbée par la mesure du flux de sève xylémique a permis de tester le modèle. L'estimation du taux de transpiration par la canopée dérivé du modèle par la mesure du flux xylémique concorde à $\pm 20 \%$, spécialement lorsque les déficits de pression de vapeur sont modérés ou élevés. Les résultats suggèrent que les changements dans la structure de la canopée, dépendant de l'âge et la densité et leurs effets sur l'exposition à la lumière de l'aiguille moyenne conduisent

* Correspondence and reprints

Tel. (49) 921.55.2576; Fax. (49) 921.55.2564; e-mail: falge@uni-bayreuth.de 
à un décalage dans la conductance de la canopée et déterminent la transpiration dans la canopée de l'arbre de ces forêts aménagées de montagne. Les taux de photosynthèse nette modélisés de la canopée sont présentés, mais n'ont pas encore été validés au niveau des mesures.

épicéa / modèle tridimentionnel STANDFLUX / flux de sève / transpiration de la canopée / efficience d'utilisation de la lumière / interaction biosphère-atmosphère

\section{INTRODUCTION}

Long-term eddy covariance measurements over temperate forests are now more commonly used to quantify annual net ecosystem $\mathrm{CO}_{2}$ exchange of different forest types $[4,22,64]$. It is anticipated that flux measurement networks will help clarify the role played by temperate forests in the global carbon cycle [4]. However, large variation and uncertainty exists in eddy-flux estimates obtained under seemingly similar environmental conditions. These problems may be due in part to the continuous shifts in the footprint along with the heterogenous nature of forest ecosystems. For a better interpretation of eddy covariance signals, as well as whole ecosystem response, it is important to improve our understanding of natural variation in processes that occur within individual ecosystem compartments, e.g., to describe functional heterogeneity that occurs in the vicinity of experimental towers, to map structure within the footprint area of the towers $[3,61]$, and to eventually associate specific measurements of gas exchange with processes occurring at specific locations [64].

Xylem sapflow methods provide a means of characterizing local water use by the forest canopy [e.g., 16, $24,34,35,40,41,48,50]$. Sapflow sensors were used in six spruce stands of differing ages within a montane catchment in the Lehstenbach watershed (Fichtelgebirge, Germany) in order to examine time dependent changes in tree canopy transpiration [1]. As stands age in these montane forests, density decreases from several thousand trees per hectare to only several hundred per hectare, as a result of both management activities, and natural self-thinning. Along with these structural changes, tree canopy transpiration decreases to half of the rate found in young stands even though stand total leaf area remains high [1].

A three- dimensional gas exchange model (STANDFLUX; cf. [18]), which includes sub-models for light interception and for gas exchange of individual branches or leaves, was used to examine variation in tree canopy gas exchange of the six Norway spruce canopies. The model accounts for site-specific stand structure, and estimates gas exchange for clusters of trees, each tree with foliage distributed within vertical layers and horizontally in a series of concentric cylinders. This study investi- gates whether the observed differences in tree transpiration result from physiological changes or due to altered clumping of the foliage in the canopy. Associated changes in canopy net photosynthesis and water use efficiencies are also predicted, but these have not yet been independently validated.

\section{METHODS}

\subsection{Field research sites}

Structural characteristics were determined for six Norway spruce stands occurring in proximity in the Fichtelgebirge in Northern Bavaria (Lehstenbach catchment, latitude $50^{\circ} 9^{\prime} \mathrm{N}$, longitude $11^{\circ} 52^{\prime} \mathrm{E}$, c.a. $775 \mathrm{~m}$ above sea level). The stands differed either in age and structure, in exposition, or in soil characteristics (Table I). In the following text, the 40 year-old stands Weiden Brunnen, Schanze, and Schlöppner Brunnen with low, medium, and high cumulative basal areas will be referred to as "40LB", "40MB", and "40HB" respectively, the older stands Süßer Schlag, Gemös, and Coulissenhieb according to their age will be referred to as "70", "110", and "140". Tree density varied between 320 and 1680 trees per ha $^{-1}$, average projected leaf area index (LAI) determined via harvesting methods varied between 5.3 and $7.9 \mathrm{~m}^{2} \mathrm{~m}^{-2}$. Average tree height in the stands is between c.a. 15 and $26 \mathrm{~m}$. The soils are permeable brown earths and podsols on phyllite and gneiss. During the period 1992 to 1994, the mean annual temperature was $5.8^{\circ} \mathrm{C}$, the mean January temperature was $-1.0{ }^{\circ} \mathrm{C}$, and the mean in July was $15.6{ }^{\circ} \mathrm{C}$. Mean annual precipitation during this period was $885 \mathrm{~mm}$.

\subsection{Observations of Sap flow}

Investigations were carried out in 1994 and 1995 from the middle of April to the middle of November (see details in Alsheimer et al. [1]). In each stand, sapflow installations were made on 10 trees except in the case of the 140-year-old stand where 12 to 13 trees were examined. Two methods for measuring xylem sapflow were used: dynamic thermal flowmeters constructed according to Granier [23, 24] and the steady-state, null-balance 
Table I. Stand characteristics as used in the model parameterization for six Norway spruce stands in the Lehstenbach catchment in the Fichtelgebirge, Northern Bavaria. See also Alsheimer et al. (1998).

\begin{tabular}{|c|c|c|c|c|c|c|}
\hline Site & $\begin{array}{l}\text { Weiden Brunnen } \\
\text { "40LB" }\end{array}$ & $\begin{array}{l}\text { Schanze } \\
\text { "40MB" }\end{array}$ & $\begin{array}{l}\text { Schlöppner Brunnen } \\
\text { "40HB" }\end{array}$ & $\begin{array}{c}\text { Süßer Schlag } \\
\text { "70" }\end{array}$ & $\begin{array}{l}\text { Gemös } \\
\text { "110" }\end{array}$ & $\begin{array}{l}\text { Coullisenhieb } \\
\text { "140" }\end{array}$ \\
\hline Stand age (years) & 40 & 40 & 40 & 70 & 110 & 140 \\
\hline Exposition & southwest & northeast & south & southeast & south & southwest \\
\hline Tree density (tree ha-1) & 1010 & 1010 & 1680 & 500 & 450 & 320 \\
\hline Mean stand height (m) & 16.1 & 17.8 & 14.7 & 24.1 & 25.7 & 25.2 \\
\hline Mean crown length $(\mathrm{m})$ & 10.0 & 7.7 & 6.4 & 11.5 & 13.8 & 11.4 \\
\hline Mean crown projection $\left(\mathrm{m}^{2}\right)$ & 10.3 & 7.2 & 7.7 & 18.6 & 18.8 & 22.0 \\
\hline Mean circumference at & 60.0 & 66.4 & 50.5 & 108.7 & 107.6 & 115.2 \\
\hline breast height $(\mathrm{cm})$ & $( \pm 16.3)$ & $( \pm 18.5)$ & $( \pm 19.9)$ & $( \pm 19.1)$ & $( \pm 22.4)$ & $( \pm 23.5)$ \\
\hline Cumulative basal area $\left(\mathrm{m}^{2} \mathrm{ha}^{-1}\right)$ & 30.9 & 37.8 & 39.5 & 48.8 & 42.4 & 35.3 \\
\hline LAI $\left(\mathrm{m}^{2} \mathrm{~m}^{-2}\right)$ & 5.3 & 7.1 & 6.5 & 7.9 & 7.6 & 6.5 \\
\hline Understory cover (\%) & 66 & 19 & 23 & 85 & 76 & 83 \\
\hline
\end{tabular}

method of Cermák et al. [14, 15]; Kucera et al. [37]; and Schulze et al. [62].

With the Granier methods applied in all stands, cylindrical heating and sensing elements were inserted into the trunks at breast height, one above the other c.a. $15 \mathrm{~cm}$ apart, and the upper element was heated with constant power. The temperature difference sensed between the two elements was influenced by the sap flux density in the vicinity of the heated element. Sap flux density was estimated via calibration factors established by Granier [23].

The steady-state, null-balance instrumentation was used to obtain an additional estimate of water use by individual trees within the 140 year-old stand. A constant temperature difference of $3 \mathrm{~K}$ was maintained between a sapwood reference point and a heated stem section. The mass flow of water through the xylem of the heated area is proportional to the energy required in heating.

Total sapflow per tree was obtained by multiplying sap flux density by the cross-sectional area of sapwood at the level of observation [1]. Sapwood area of sample trees was estimated from regressions, relating CBH (circumference at breast height) to sapwood area determined either with an increment borer, by computer tomography $[26,27]$, or from stem disks of harvested trees. The upscaling of canopy fluxes from xylem sap flow measurements was obtained by multiplying average flux densities (sapflow per sapwood area) of ten (for stand "140" 14) representative trees by total sapwood of the stand and dividing by the ground surface area. The trees were selected to best represent the $\mathrm{CBH}$ distribution of the canopy, and, therefore, of varying $\mathrm{CBH}$ and sapwood area, affecting their relative contribution to total canopy fluxes.

\subsection{Model description}

\subsubsection{Branch gas exchange model}

Photosynthesis of needled branches was described according to Farquhar et al. [21] and Harley and Tenhunen [28]. Stomatal conductance was included according to Ball et al. [5] as described in Falge et al. [17]. Details of the application are described in Appendix 1.

\subsubsection{Gas exchange of individual trees and canopies}

The model STANDFLUX [18] calculates water use and $\mathrm{CO}_{2}$ fixation of individual target trees surrounded by trees of varying size and structure, considering speciesspecific leaf physiology, three dimensional radiation interception, and vertical microclimate gradients. One tree consists of a series of concentric cylinders and vertical layers. The resultant subsections are characterized by homogeneous leaf and stem densities as well as leaf and stem angles as derived from tree harvests. The light interception submodel calculates direct beam and sky diffuse radiation (PPFD) for each point of a cubic matrix superimposed over the tree. Single tree transpiration in STANDFLUX is calculated using a leaf area weighted sum of the rate of water use in all subsections of the tree (determined by multiplying the average transpiration rate for all matrix points in the subsection by the leaf area of the subsection and then summing subsections - see Falge et al. [18]). Details of the light interception algorithms and tree structural description are given in Ryel [57], Ryel et al. [58], and Falge et al. [18].

The contribution of the tree classes - defined by tree size - to canopy gas exchange is estimated from the frequency of occurrence of the different classes in the 
canopy. With information on the $(x, y)$ coordinates of the trees in the stand, the gas exchange of a cluster of trees with clumped leaf area similar to observation can be calculated. Such clusters of trees were the subject of sapflow observations as reported by Alsheimer et al. [1]. Thus, the model provides a good representation of the actual experimental situation. For model parameterization, structural information such as tree height, crown length, crown projection area, distribution of leaf area density (LAD), distribution of stem area density (SAD), leaf angles, and stem angles in subsections are required.

\subsection{Model parameterization}

\subsubsection{Canopy and individual tree structure}

The positions of trees in each stand and their crown projections are illustrated in figure 1. Shaded crowns indicate those trees on which sapflow was measured.
The frequency distribution of tree circumferences at breast height $(\mathrm{CBH})$ was obtained at the six locations, and found to be normally distributed (data not shown) with the lowest mean of 50.5 at "40HB" (table I) and highest of $115 \mathrm{~cm}$ at "140". Tree heights and crown lengths were measured with a Suunto-Hypsometer (PM5/ 1520 PCP, 02920 Espoo, Finland). Crown projection areas (CPA) were estimated from below the crown by vertical sighting at eight locations around each tree. The octagonal CPA were used to obtain circular approximations for the cylindrically modelled trees. Off-centered trunks were re-centered within the resulting CPAs to accommodate STANDFLUX. CBH was used to define five tree size classes. A representative tree from each class was harvested to estimate leaf surface and projected stem area densities within the crowns (table II). The harvested trees were cut into one- meter sections. From each section, a subset of sample branches were used to determine bare and needled length of branches and needle mass as related to branch basal diameter. With the
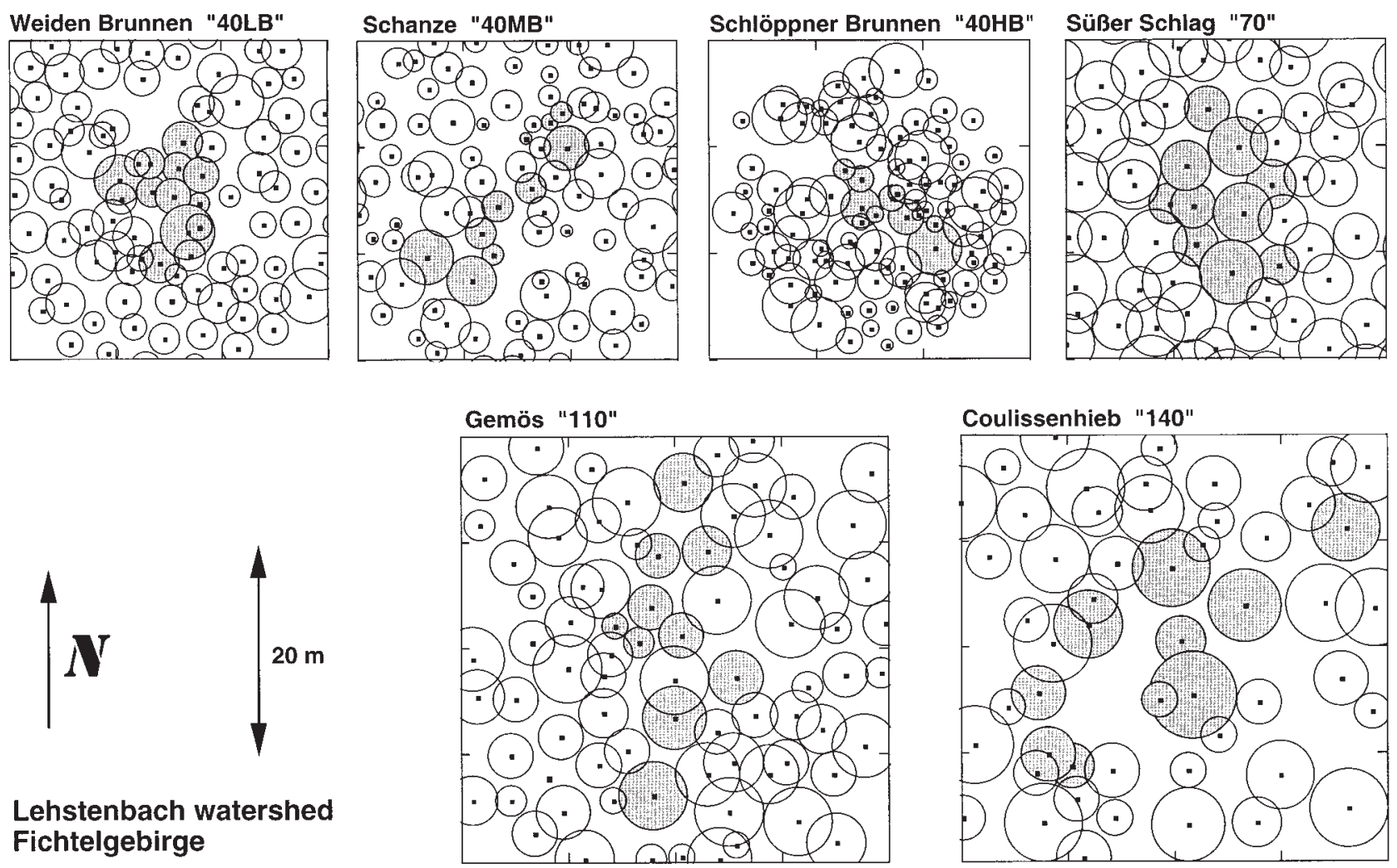

Figure 1. Relative tree positions and crown projected areas of the trees at the research sites in the Fichtelgebirge, Germany. Circular crown projections (CPA) were used to accommodate STANDFLUX; gray CPAs indicate the trees used for xylem sapflow measurements. 
Table II. Coefficients of a power function to calculate average needle surface area (LSA, $\mathrm{m}^{2}$ tree $\mathrm{e}^{-1}$ ) and average projected stem area $\left(\mathrm{SAI}, \mathrm{m}^{2}\right.$ tree $\left.^{-1}\right)$ from the circumference at breast height $(\mathrm{CBH}, \mathrm{cm})$ for the four different age classes of Norway spruce stands, used for the STANDFLUX parameterization of leaf and stem area densities.

\begin{tabular}{|c|c|c|c|c|c|c|c|}
\hline \multirow[t]{2}{*}{ Sites } & \multirow{2}{*}{$\begin{array}{c}\text { Number } \\
\text { of trees } \\
n\end{array}$} & \multicolumn{3}{|c|}{$\begin{array}{c}\mathrm{LSA}=a^{\star} \mathrm{CBH}^{b} \\
\left(\mathrm{LSA} \text { in } \mathrm{m}^{2} \text { tree }^{-1}, \mathrm{CBH} \text { in } \mathrm{cm}\right)\end{array}$} & \multicolumn{3}{|c|}{$\begin{array}{c}\mathrm{SAI}=a^{*} \mathrm{CBH}^{b} \\
\left(\mathrm{SAI} \text { in } \mathrm{m}^{2} \text { tree }^{-1}, \mathrm{CBH} \text { in } \mathrm{cm}\right)\end{array}$} \\
\hline & & $a$ & $b$ & $r^{2}$ & $a$ & $b$ & $r^{2}$ \\
\hline 40-year-old & 15 & 0.00116 & 2.81 & 0.93 & 0.000110 & 2.83 & 0.89 \\
\hline 70-year-old & 5 & 0.00514 & 2.39 & 0.68 & 0.000048 & 2.41 & 0.59 \\
\hline 110-year-old & 5 & 0.00520 & 2.39 & 0.83 & 0.000043 & 2.40 & 0.78 \\
\hline 140-year-old & 5 & 0.00685 & 2.35 & 0.95 & 0.000062 & 2.38 & 0.91 \\
\hline
\end{tabular}

regressions obtained, the needle mass of remaining branches was estimated from their basal diameters and distributed along the tree according to mapped branch insertion points. Analogously, the branch mass and branch surface areas were determined.

Leaf area density (LAD) and stem area density (SAD) for single crown volumes were calculated from the respective absolute areas (leaf surface and stem projected area, LSA and SAI) according to the dependencies on $\mathrm{CBH}$ given in table II. The conversion used to obtain effective leaf area for light interception from LSA is given in Appendix 2. Horizontal and vertical changes in LAD and SAD in model trees were not considered in this application. Individual trees were constructed of two layers and two cylinders, but ten different tree size classes in the canopy were used. Considering the actual range of stand LAI encountered, simplification of the tree structure did not influence modelled water flux. Daily sums of transpiration are not affected at average canopy LAI above 5.3 (see sensitivity analysis in Falge et al. [18]), while underestimation of daily sums of canopy net photosynthesis increases from zero at a canopy LAI of 5.3 to $10 \%$ at a canopy LAI of 8.0 (Falge et al. [18], their figure 5).

\subsubsection{Physiological parameterization}

The physiological parameters for the Norway spruce branch gas exchange model (PSN6) were determined independently by means of cuvette gas exchange measurements of branches with up to 3 needle age classes [17] and were not adjusted in the process of examining xylem sapflow data. No information was available for needle gas exchange for trees of different age in the Fichtelgebirge, but Falge et al. [17] showed that parameters derived from 30-50 year-old spruce trees could be transferred to a 120 year-old tree in Lägeren (Switzerland), sufficiently reproducing measured gas exchange rates. In this study, the gas exchange reaction for needles of all stands and for the entire tree crowns was described using a shade leaf parameterization determined appropriate for the Fichtelgebirge region with high LAI (table III). The physiological capacity of Norway spruce needles for electron transport, carboxylation, and dark respiration varies seasonally in agreement with gas exchange observations from several other tree species [10, 12, 47, 49]. We assumed that reduced soil water availability did not affect stomatal conductance during the summers 1994 and 1995 due to frequent rain events.

\subsubsection{Meteorological drivers}

The measurement of radiation, air temperature above and below the canopy, humidity, wind speed, $\mathrm{CO}_{2}$ concentration, and atmospheric pressure for the modelling of the Norway spruce canopies in the Fichtelgebirge was described in Falge et al. [18]. The measurements were obtained with a 30 meter high telescope mast [32], during 1994 at "40LB", and 1995 at "140" (figures 2 and 3). Hourly means of the data stored at 10-minute intervals were used for the simulations. The stands "40LB" and "140" were immediately adjacent and the same meteorological conditions were used for both. For the sites "40MB", "40HB", and "70", temperature and vapor pressure deficit of the air at the top of the canopy were measured. Compared to "40LB" and "140", the temperatures at "40MB", "40HB" and "70" were about $12 \%$ lower; vapor pressure deficit of the air was on average $10 \%$ lower for " $40 \mathrm{HB}$ " and "70", and $20 \%$ lower for "40MB", the north-east facing site. For "110" no meteorological measurements were conducted on the site and inputs to the model were assumed the same as "40LB" and "140". Differences in soil surface temperatures and canopy wind profiles were not considered in this modelling application. Although wind speed influences the boundary layer conductance of leaves or branches, the boundary layer conductance in coniferous forests is approximately an order of magnitude greater than 
Table III. Constants and activation energies utilized to determine temperature and light dependent values of the photosynthesis mdoel parameters for branches of Norway spruce in the Fichtelgebirge region. Parameters give seasonal variability of gas exchange on a needle surface area. For definition of the parameters, and carboxylase kinetics see Falge et al. [17].

\begin{tabular}{|c|c|c|c|c|}
\hline & Parameter & & Values & Units \\
\hline $\begin{array}{l}\text { Dark } \\
\text { Respiration }\end{array}$ & $\begin{array}{c}E_{\mathrm{a}}\left(R_{\mathrm{d}}\right) \\
f\left(R_{\mathrm{d}}\right)\end{array}$ & $\begin{array}{l}\text { May-June } \\
\text { July-Aug. } 15 \\
\text { Aug. 16-Sept. } \\
\text { Oct.-April }\end{array}$ & $\begin{array}{c}63500 \\
64500 \\
64000 \\
64000 \\
25\end{array}$ & $\begin{array}{l}\mathrm{J} \mathrm{mol}^{-1} \\
\mathrm{~J} \mathrm{~mol}^{-1} \\
\mathrm{~J} \mathrm{~mol}^{-1} \\
\mathrm{~J} \mathrm{~mol}^{-1}\end{array}$ \\
\hline $\begin{array}{l}\text { Electron } \\
\text { transport } \\
\text { capacity }\end{array}$ & $\begin{array}{c}c\left(P_{\mathrm{ml}}\right) \\
\\
\Delta H_{\mathrm{a}}\left(P_{\mathrm{ml}}\right) \\
\Delta H_{\mathrm{d}}\left(P_{\mathrm{ml}}\right) \\
\Delta S\left(P_{\mathrm{ml}}\right)\end{array}$ & $\begin{array}{l}\text { May-June } \\
\text { July-Aug. } 15 \\
\text { Aug. 16-Sept. } \\
\text { Oct.-April }\end{array}$ & $\begin{array}{c}19.55 \\
19.20 \\
19.30 \\
19.35 \\
55000 \\
215000 \\
725\end{array}$ & $\begin{array}{c}- \\
- \\
- \\
- \\
\mathrm{J} \mathrm{mol}^{-1} \\
\mathrm{~J} \mathrm{~mol}^{-1} \\
\mathrm{~J} \mathrm{~K}^{-1} \mathrm{~mol}^{-1}\end{array}$ \\
\hline $\begin{array}{l}\text { Carboxylase } \\
\text { capacity }\end{array}$ & $\begin{array}{c}c\left(V c_{\max }\right) \\
\Delta H_{\mathrm{a}}\left(V c_{\max }\right) \\
\Delta H_{\mathrm{d}}\left(V c_{\max }\right) \\
\Delta S\left(V c_{\max }\right)\end{array}$ & $\begin{array}{l}\text { May-June } \\
\text { July-Aug. } 15 \\
\text { Aug. 16-Sept. } \\
\text { Oct.-April }\end{array}$ & $\begin{array}{c}34.50 \\
34.25 \\
34.30 \\
34.30 \\
77000 \\
215000 \\
725\end{array}$ & $\begin{array}{c}- \\
- \\
- \\
- \\
\mathrm{J} \mathrm{mol}^{-1} \\
\mathrm{~J} \mathrm{~mol}^{-1} \\
\mathrm{~J} \mathrm{~K}^{-1} \mathrm{~mol}^{-1}\end{array}$ \\
\hline $\begin{array}{l}\text { Carboxylase } \\
\text { kinetics }\end{array}$ & $\begin{array}{c}f\left(K_{\mathrm{c}}\right) \\
E_{\mathrm{a}}\left(K_{\mathrm{c}}\right) \\
f\left(K_{\mathrm{o}}\right) \\
E_{\mathrm{a}}\left(K_{\mathrm{o}}\right) \\
f(\mathrm{t}) \\
E_{\mathrm{a}}(\mathrm{t})\end{array}$ & & $\begin{array}{c}31.95 \\
65000 \\
19.61 \\
36000 \\
-3.9489 \\
-28990\end{array}$ & $\begin{array}{c}- \\
\mathrm{J} \mathrm{mol}^{-1} \\
- \\
\mathrm{J} \mathrm{mol}^{-1} \\
- \\
\mathrm{J} \mathrm{mol}^{-1}\end{array}$ \\
\hline $\begin{array}{l}\text { Light use } \\
\text { efficiency }\end{array}$ & $\alpha$ & & 0.015 & $\mathrm{~mol} \mathrm{CO}_{2}$ (mol photons) $)^{-1}$ \\
\hline $\begin{array}{l}\text { Stomatal } \\
\text { conductance }\end{array}$ & $\begin{array}{l}g_{\min } \\
g_{\text {fac }}\end{array}$ & & $\begin{array}{c}0 \\
9.8\end{array}$ & $\begin{array}{c}\mathrm{mmol} \mathrm{m} \mathrm{m}^{-2} \mathrm{~s}^{-1} \\
-\end{array}$ \\
\hline
\end{tabular}

stomatal conductance [33], and therefore effects of changed wind profiles on canopy conductance are low.

\subsection{Simulations}

Simulations of canopy $\mathrm{CO}_{2}$ and $\mathrm{H}_{2} \mathrm{O}$ exchange were carried out for the periods May through September 1994 and April through October 1995. Since there is a time lag between the onset of transpiration in the canopy and measured flow of water in the trunk [e.g., 29], i.e., the model represents leaf responses while sapflow is influenced further by internal water storage, model validation at the individual tree level involves comparing the integrated daily sums of measured and estimated water use.
Stand level transpiration and net $\mathrm{CO}_{2}$ fixation is estimated as the transpiration and net photosynthesis rate of the mean individual tree in each size class multiplied by the number of trees per ground area in the class, and then by integrating over all classes. Although simulations for virtual canopies showed high variation within a tree class (Falge et al. [18], their table V), calculations in the current application were performed only for one tree per class, namely that used for xylem sapflow measurements. This approach allowed comparisons at single tree level and reduced computer calculation time. While stand transpiration rate represents water loss through the tree crowns, net $\mathrm{CO}_{2}$ fixation is calculated for needled branch ends, e.g., maintenance or growth respiration for the woody (bare) component of the canopy is not included. 


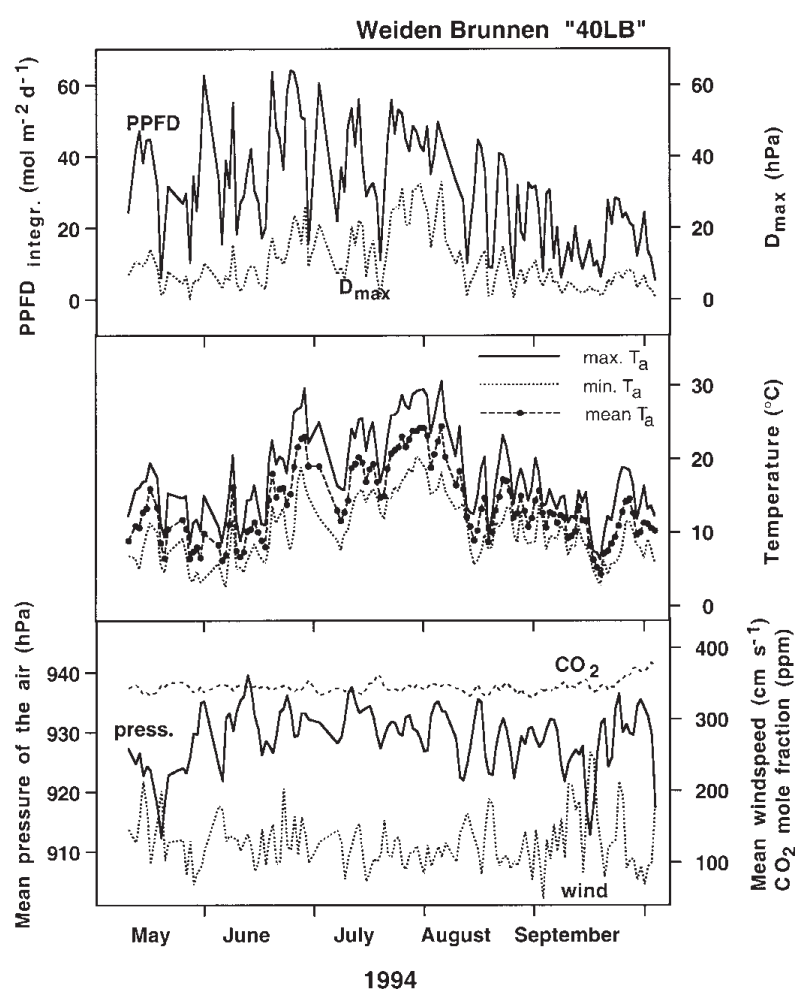

Figure 2. Daily sums of daily photosynthetic photon flux density $\left(P P F D_{\text {integr. }}\right)$, maximum saturation deficit of the air $\left(D_{\max }\right)$, maximum, minimum, and mean daily temperature above the canopy (max. Ta, min. Ta, and mean Ta), atmospheric pressure, $\mathrm{CO}_{2}$ concentration and wind speed above the Weiden Brunnen stand "40LB" from May until October 1994.

\section{RESULTS}

The daily integrated sums of model-estimated and measured transpiration (liters per tree and day) of ten 40year-old individual trees at "40LB" and ten 140-year-old individual trees at "140" are compared in figure 4 for the study periods of 1994 and 1995. The different symbols for the measurements at "140" indicate data originating from the different xylem sap flow measurement systems ("Granier" and "Cermák/Schulze", see Methods). Fluxes at "40LB" are much smaller than for "140", as the trees at "40LB" are much smaller and had less leaf area per tree $\left(52 \mathrm{~m}^{2}\right.$ per tree) than those at " 140 " $\left(203 \mathrm{~m}^{2}\right.$ per tree). The relationship between modelled daily tree transpiration and measured daily xylem sap flow was linear for most trees. However, the slope of the regression line for individual trees at Weiden Brunnen varies between 0.4 and 1.7 (with $r^{2}$ between 0.67 and 0.90 ), at Coulissenhieb between 0.6 and 3.2 (with $r^{2}$ between 0.74

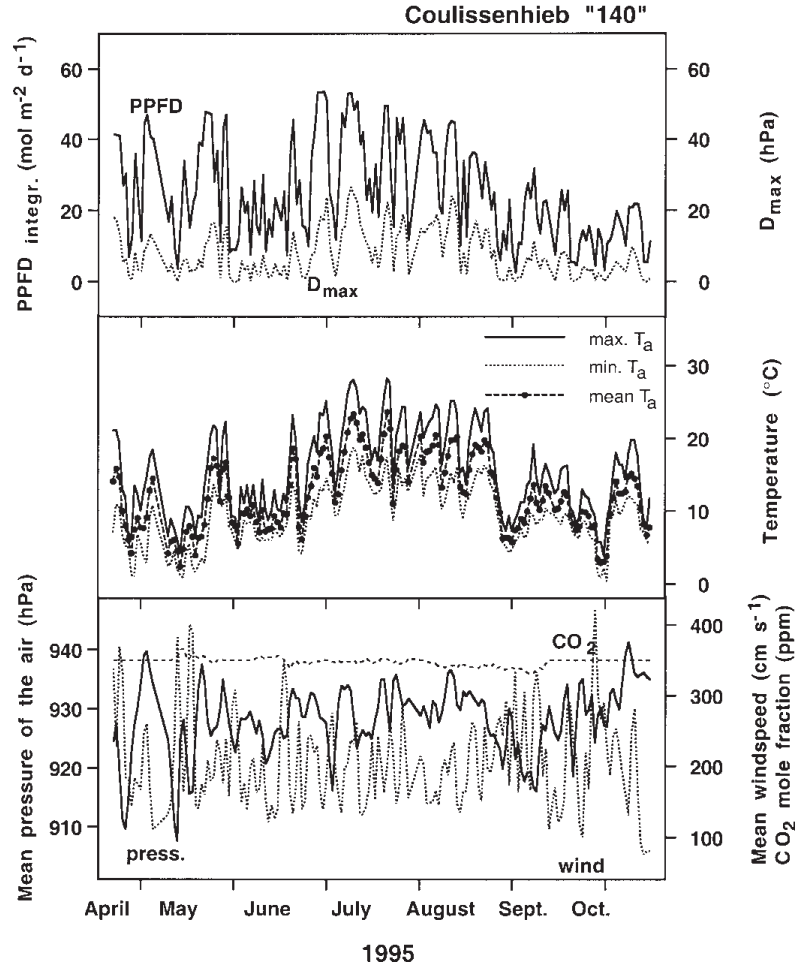

Figure 3. Daily sums of daily photosynthetic photon flux density $\left(P P F D_{\text {integr }}\right)$, maximum saturation deficit of the air $\left(D_{\text {max }}\right)$, maximum, minimum, and mean daily temperature above the canopy (max. Ta, min. Ta, and mean Ta), atmospheric pressure, $\mathrm{CO}_{2}$ concentration and wind speed above the Coulissenhieb stand "140" from April until October 1995.

and 0.89). Potential reasons for slopes differing from 1 are given in the discussion. Individual trees are not equally representative for the canopy (see above, Observation of Sap flow), but after weighted pooling of the results from all trees, a relatively good agreement between measured and modelled rates is found.

Figure 5 shows the comparison of modelled transpiration rates and measured xylem sap flow rates at the canopy level [1] for the six Norway spruce stands. Changes in transpiration rate due to daily variation in light, temperature and humidity are reproduced well by STANDFLUX with $r^{2}$ for the comparison regression line from 0.82 to 0.95 , and slopes of the linear regression between c.a. 0.84 to 1.01 (see table IV). Absolute deviation of the model estimates of canopy transpiration from estimates based on xylem sapflow measurements can reach up to $0.5 \mathrm{~mm}$ per day (figure 6). However, especially when maximum daily water vapor saturation 


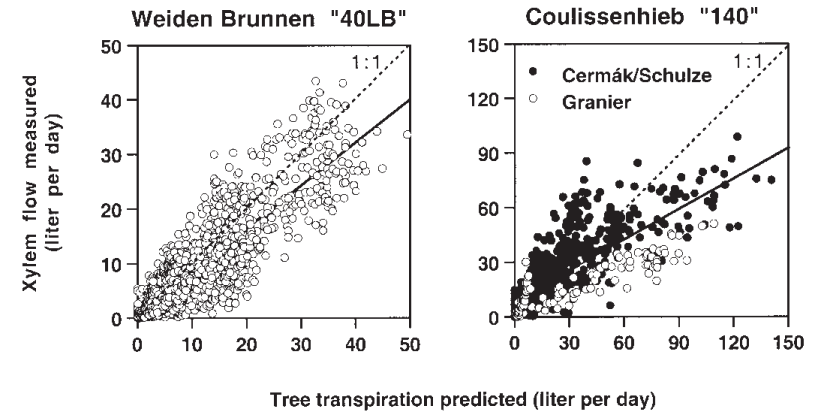

Figure 4. Comparison of daily estimates of water use obtained via xylem sap flow methods and from the canopy model for transpiration of single trees at the Weiden Brunnen "40LB" $\left(r^{2}=0.77\right)$ and Coulissenhieb "140" $\left(r^{2}=0.64\right)$ sites during the periods of 1994 and 1995 described in figures 2 and 3.

deficit $\left(D_{\max }\right)$ is above $8 \mathrm{hPa}$ (solid symbols), the deviation amounts to a maximum of c.a. $\pm 20 \%$ of the transpiration rate. At lower values for $D_{\max }$, relatively large percentual over- and under-estimates of daily water use may occur (open symbols in figure 6), possibly due to lower measurement accuracy at low sap flow rates. Deviations appeared similar for both young and old stands, although transpiration rates remain much lower in the 140-year old stand.

Monthly sums of modelled canopy transpiration for the two summer periods are compared with measurements for the six Norway spruce stands in figure 7. A better agreement is found than on a daily basis due to error compensation of time integration. Observed and modelled monthly transpiration sums change in the rela-

Table IV. Coefficients of a linear regression between modelled and measured daily sums of transpiration for the six Norway spruce stands in the Lehstenbach-catchment, for the vegetation period 1994 and 1995 (“40LB", “40HB”, and "140”) and 1995 ("40MB", "70", and "110").

\begin{tabular}{lccc}
\hline$E_{\mathrm{c}, \text { meas }}=a^{*} E_{\mathrm{c}, \text { mod }}+b$ & & & \\
$\left(E_{\mathrm{c}}\right.$ in mm d & & & \\
& & & \\
"40LB" (Weiden Brunnen) & 0.837 & 0.053 & 0.94 \\
"40MB") (Schanze) & 0.920 & -0.101 & 0.93 \\
"40HB" (Schlöppner Brunnen) & 1.006 & 0.043 & 0.95 \\
"70" (Süßer Schlag) & 0.916 & 0.028 & 0.95 \\
"110" (Gemös) & 0.896 & 0.170 & 0.93 \\
"140" (Coulissenhieb) & 0.679 & 0.134 & 0.82 \\
\hline
\end{tabular}

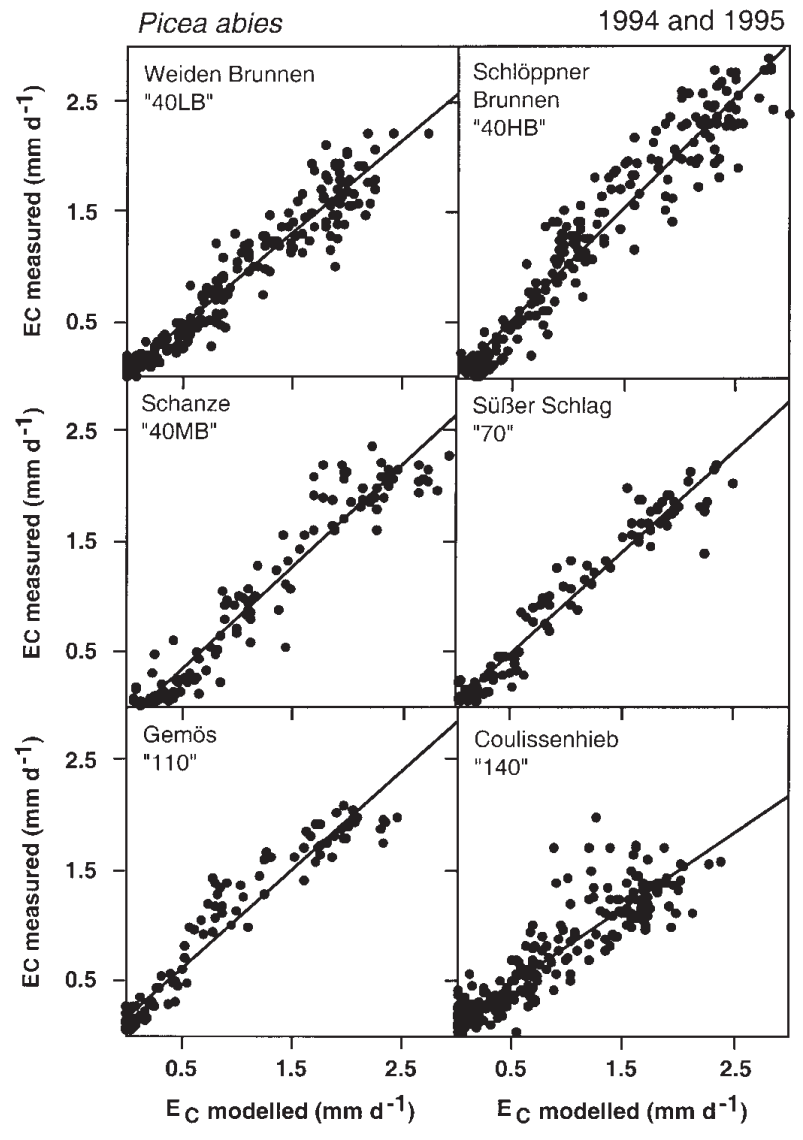

Figure 5. Comparison of measured and modelled daily canopy transpiration of the six Norway spruce canopies (see table I for stand descriptions) during the summer of 1994 ("40LB", "40HB", and "140") and 1995 (all sites). Coefficients of the regression are given separately for the six stands in table IV.

tionship to the maximum saturation deficit of the air $\left(D_{\max }\right)$ and the level of daily radiation input (indicated as symbols in the lower panel of the figure). Monthly canopy carbon gain calculated with STANDFLUX for the six Norway spruce stands during the summer seasons of 1994 and 1995 is illustrated in figure 8. Whereas the transpiration sums increase with increase in daily mean temperature (not shown), $D_{\max }$, and daily radiation sum, high temperatures in the summer months are predicted to limit canopy carbon gain due to low photosynthetic activity and increases in foliage dark respiration rates. The trees of the oldest stand ("140") used less water at stand level, but are also predicted to be less efficient in carbon gain. 

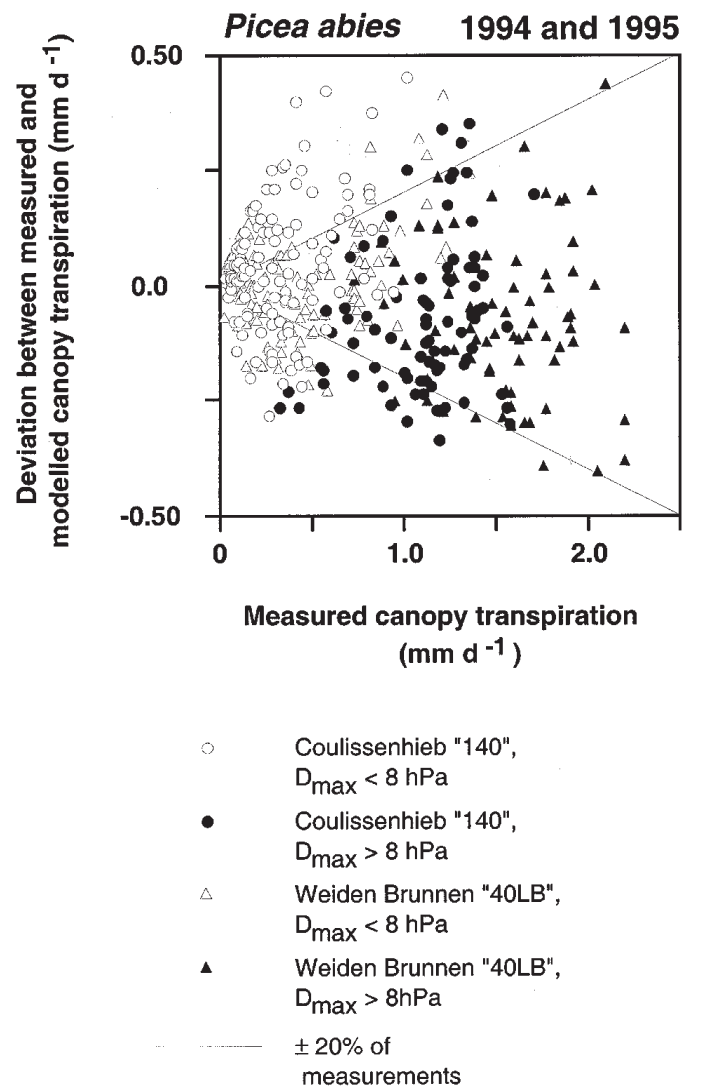

Figure 6. Differences between the model estimates and sap flow estimates of daily canopy transpiration of the 40-year-old Norway spruce canopy Weiden Brunnen "40LB" (triangles) and the 140-year-old Norway spruce canopy Coulissenhieb "140" (circles) plotted versus canopy transpiration from sap flow monitoring. Open symbols indicate days on which maximum daily water vapor saturation deficit was less than 8 hla, solid symbols are for days with greater $D_{\max }$. Negative values describe an over-estimation of the measurements by the model. The lines delimit the area corresponding to a measuring accuracy of $\pm 20 \%$.

\section{DISCUSSION AND CONCLUSIONS}

Gas exchange rates of the six Norway spruce canopies were described with the three dimensional gas exchange model STANDFLUX with one species-specific set of physiological parameters neglecting effects of tree or needle age (see below), and assuming no influence of soil water availability at the selected research sites (constant stomatal sensitivity to aboveground microclimate factors). Estimates for canopy transpiration rate derived from the model and via xylem sap flow measurements in these managed montane Norway spruce forest agree

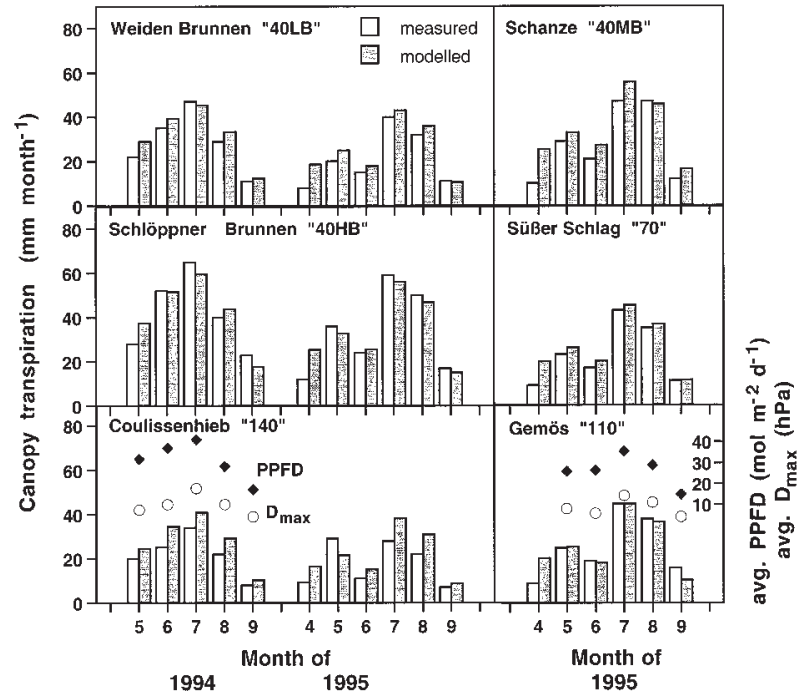

Figure 7. Monthly sums of modelled and measured canopy transpiration based on square meter ground area for six Norway spruce stands in the Lehstenbach catchment from May to September 1994 and April to September 1995. Average daily sums of photosynthetic photon flux density (PPFD, solid diamond) and average daily maximum saturation deficit of the air ( $D_{\text {, }}$, open circles) as measured above "40LB" (1994) and "140" (1995) are indicated in the lower panels of the figure.

within $\pm 20 \%$, especially at moderate to high air vapor pressure deficits. Good agreement was found in the seasonal patterns for water use obtained by both methods.

Leaf area index, or more specifically the threedimensional distribution of foliage density in a vegetation canopy, is a critical factor determining the average light intensity to which foliage elements are exposed, and therefore the degree to which foliage photosynthetic capacity is utilized, i.e., the foliage distribution determines the gas exchange rate of the average needle in these spruce stands. Since the physiological capacities of all needles were considered to be the same in STANDFLUX, the large differences in modeled gas exchange can only be ascribed to structural effects on foliage distribution (cf. figure 1) and the resulting influences on light distribution. The results suggest strongly that age and density dependent changes in canopy structure (changes in clumping of needles) and their effect on light exposure of the average needle lead to shifts in canopy conductance and determine tree canopy transpiration in these managed montane forests. Spruce stands 70-yearsold and older were characterized by fewer trees per hectare, only 70 to $90 \%$ canopy closure, relatively high leaf area indices $(\geq 6.5)$, and high per tree leaf areas 


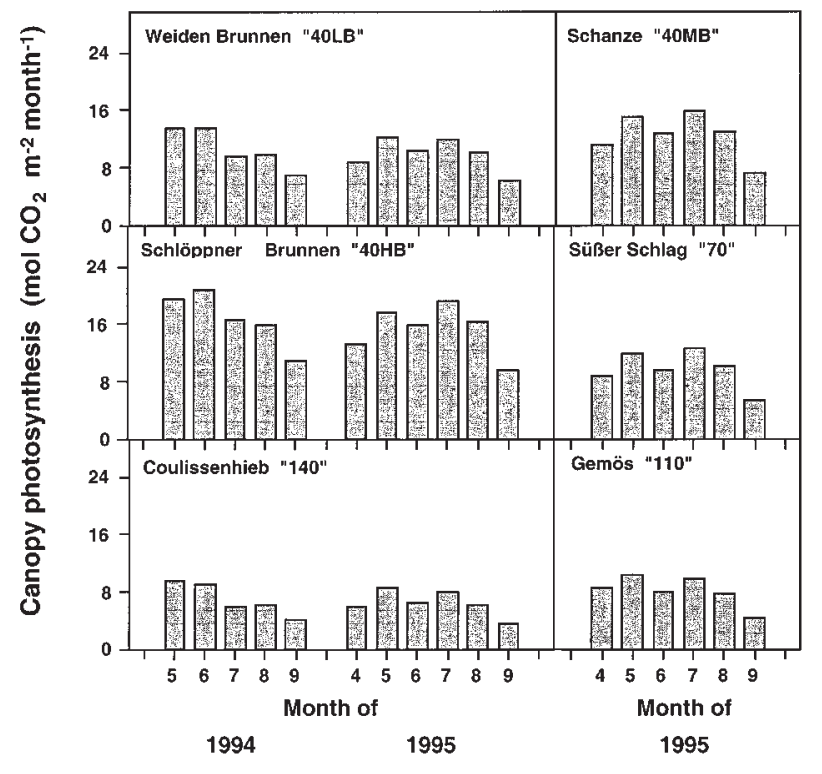

Figure 8. Monthly sums of modelled canopy carbon gain based on square meter ground area for six Norway spruce stands in the Lehstenbach catchment from May to September 1994, and April to September 1995. Carbon gain is obtained with the exclusion of aboveground woody respiration as described in the methods.

(between 158 and $203 \mathrm{~m}^{2}$ per tree). Such trees had denser foliage clumping on individual branches and denser crowns, two factors leading to increased selfshading. Thus, even on an individual tree basis, water use was reduced due to a high degree of self-shading. Decreased tree transpiration in the old stands was associated with a simultaneous decrease in sapwood area per LAI or per hectare [1]. Not surprisingly, understory cover (mainly Deschampsia flexuosa, Calamagrostis villosa, and Vaccinium myrtillus) exceeded $75 \%$ in these stands (see table I).

Silvicultural measures such as thinning will reduce the leaf area of the stand but not the clumping of foliage in the crown and self-shading. Spruce trees with their strong apical control are less able to exploit the patchy light distribution in forest canopies, and as trees age, the ability to respond to light gaps decreases. Tree architecture limits growing new leaves in areas with high light availability $[7,51]$. Due to these architectural restrictions, the older spruce crowns were less able to exploit the available crown space in terms of light interception, and as a result, transpiration and photosynthesis were reduced compared to younger stands. Contrary to our view, other authors [30, 55] have discussed decreased hydraulic conductivity in older stands as the limiting fac- tor of canopy gas exchange, whereas our results suggested an important influence of crown architecture.

Based on the modelling results as well as foliage removal experiments on young spruce trees under controlled conditions [8], it seems likely that foliage loss that occurs in the Fichtelgebirge as a consequence of acid deposition and $\mathrm{Mg}$ deficiency [63] may initially lead to only small decreases in carbon gain at the tree level, since the light climate of remaining needles may be improved. Together with increased nitrogen availability, increases in growth (as reported in Pretzsch [52]) are potentially supported.

The parameter to which single tree gas exchange rate is most sensitive is the leaf area assumed for the tree. The leaf area included for model trees are derived from their circumference using a function derived from the leaf area of harvested trees (table II). Difficulties in determining this regression, the natural variability of the leaf area of similar-sized trees, together with potential errors in sap flow estimation (assumed radial homogeneity, heat storage in the trunk, etc.) are reflected in the comparison of transpiration rates on a single tree basis (figure 4). Furthermore, hydraulic limitations and daily depletion of water stored in the trunk or branches may add an additional restriction on actual water use and an overestimation in the calculated estimate $[36,56,60$, 67]. Pooling daily results from all trees, a relatively good agreement between measured and modelled daily rates is found, indicating that up-scaled cuvette gas exchange measurements at branch level and xylem sap flow measurements deliver consistent data. For a discussion of time lags in diurnal courses of sap flow and upscaled cuvette data due to capacitances see Hinckley et al. [29].

All model applications in this study were carried out under the assumption that the canopies were sufficiently supplied with water at the Fichtelgebirge sites in 1994 and 1995. Strong decreases in stomatal conductance of Norway spruce stands were found by Biron [9] when large negative soil matrix potentials $(-0.7$ to $-0.8 \mathrm{MPa})$ occurred at $105 \mathrm{~cm}$ depth and soil water storage in the profile was low $(<150 \mathrm{~mm}$ in the first $90 \mathrm{~cm}$ ). Soil matrix potentials at $35 \mathrm{~cm}$ depth at "40LB" decreased after periods without rain in 1994 to values as low as $-0.6 \mathrm{MPa}$ and in 1995 at $20 \mathrm{~cm}$ depth as low as -0.3 $\mathrm{MPa}$. At "140", soil matrix potentials more negative than $-0.8 \mathrm{MPa}$ occurred occasionally at $20 \mathrm{~cm}$ depth during 1994 , but potentials at $90 \mathrm{~cm}$ depth decreased only to approximately $-0.45 \mathrm{MPa}$. In 1995 , soil matrix potential at $20 \mathrm{~cm}$ depth decreased only to $-0.6 \mathrm{MPa}$, and at $90 \mathrm{~cm}$ depth was never more negative than $-0.1 \mathrm{MPa}$. An examination of the deviations between modeled and measured daily canopy transpiration showed no correlation with measured soil water potentials at $35 \mathrm{~cm}$ depth 
at "140" and "40LB". As soil water availablility decreases, water potential in stem, branches and leaves as part of the potential gradient from soil to the atmosphere is expected to drop. In a recent publication, Bauerle et al. [6] emphasize the utility of the cohesion theory in interpretation of water potential gradients in trees. More generally, predawn water potential of leaves or needled branch ends serve as an integrated measure for the water status of the plant. Decreases in stomatal conductance of Norway spruce branches have been reported along with decreases in predawn water potential of branch ends to -0.7 to $-0.8 \mathrm{MPa}[25,40]$. At our study sites in the Fichtelgebirge, predawn water potential more negative than -0.5 MPa was never recorded during 1994 and 1995 [1]. Thus, we conclude that the deviations between model and measured estimates of transpiration were not influenced by water stress phenomena.

Although a single leaf physiology was assumed in the modelling and the results demonstrated a primary role for changing tree structure in determining canopy gas exchange, decreases in needle gas exchange in the Fichtelgebirge are well documented in response to needle aging and the turnover of magnesium [39]. Older needles can show a reduction of photosynthesis and conductance of up to $50 \%$. The shade needle parameterization derived for 0-2 year-old needles applied in the current study could mean that gas exchange rates in the older stands is overestimated as leaf area accumulates in older needle classes. Approximately $25 \%$ of the needles at "140" are older than four years, while four-year-old needles were seldom found at "40LB". Alternatively, occurrence of sun or high-light adapted needles in the exposed outer crown could lead to compensating effects [38] and a good average prediction of tree gas exchange.

The current study which helps clarify heterogeneity for Norway spruce forest in the water flux contribution from the tree canopy compartment with sap flow methods must be complemented by direct measurements of evapotranspiration from the soil surface and understory. The soil surface flux varies strongly with age due to differences in stand density and radiation penetration through the stand to the ground. The view obtained of compensatory water loss from these compartments can aid in deciding whether to consider the total flux of water to the atmosphere from forest stands as a conservative process sensu Roberts [53]. Alternatively, shifts in activity from the tree canopy layer to the ground surface and understory could mean that total fluxes also change due to altered characteristics in their regulation by the organisms present.

Changes in total fluxes with alterations in stand structure seem even more likely for total $\mathrm{CO}_{2}$ flux than for evapotranspiration. Carbon dioxide exchange primarily regulated by spruce needle physiology in young spruce stands with a closed canopy will decrease with stand aging, while $\mathrm{CO}_{2}$ exchange by grasses invading gaps will increase, as will the activity of microorganisms in response to altered soil environment (warmer but possibly drying in a different time dependent manner). The $\mathrm{CO}_{2}$ exchange of clear-cut areas and mature closed forests provides estimates of the extremes that occur for measured fluxes, it is important to increase our understanding of flux variation that occurs in intermediate stages and with intermediate forest structures, as shown for instance by Buchmann et al. [13]. Based on measurements of needle gas exchange [17] and gas exchange of branches without needles and trunks [42], we have obtained a view on changing activity in carbon gain of the tree canopy compartment with stand age for Norway spruce as well as for water use. It should be possible to verify these changes with a skillful application of eddy covariance techniques above and below the canopy, such that the difference is directly comparable to the output of STANDFLUX. This must be complemented with systematic investigations of $\mathrm{CO}_{2}$ exchange by the understory plants and soil compartment of the spruce forest ecosystem.

Spruce forest density is a critical factor determining forest/atmosphere exchange, but it is also a characteristic easily determined by remote sensing. Furthermore, managed spruce forest is a landscape element with wide distribution within Europe. Thus, the results from our study, appropriately coupled to below canopy fluxes, may be generalized over larger areas, e.g., in determining water use of forested catchments. For such applications, we must still determine the potential effect of additional factors such as soil water availability or variation in leaf physiological parameters in response to gradients in temperature, $\mathrm{N}$-deposition, etc.

Importantly, it should be recognized that STANDFLUX is too costly in parameterization and computation time to be used directly for landscape and regional applications. Direct spatial application of the threedimensional model is necessary to achieve better understanding of fluxes from different sources in the vicinity of a tower for eddy covariance measurements, but landscape level estimates of gas exchange will be better achieved through use of homogeneous-layered models describing vegetation light interception, canopy microclimate, and canopy gas exchange that have been in use for several decades [e.g., 45, 43, 46, 54, 59, 66]. The question that must be answered is how to correctly parameterize such models for the complex structural situation found in forest stands. We might expect the answer to this question to be provided by combining information from direct eddy covariance measurements which 
provide the ultimate calibration and test data sets and from analyses and principles determined from models such as STANDFLUX. By comparing the output of different types of models to measured flux data, "equivalent descriptions" may be achieved [65] and the simpler layered models can then be used in designing strategies for generalizing biological information for landscapes and regions.

Acknowledgements: Financial support was provided from the Bavarian Climate Research Programme (BayFORKLIM), the Bundesministerium für Bildung, Wissenschaft, Forschung und Technologie, Germany (BEO 51-0339476A), and the EUROFLUX project (ENV4-CT95-0078). We thank Dr. Uelo Niinemets for helpful comments on an earlier version of the manuscript.

\section{Appendix 1}

\section{The branch gas exchange model PSN6}

The model PSN6 is based on the enzyme kinetics of ribulose-1,5-bisphosphate carboxylase-oxygenase (RubisCO) describing net photosynthesis as a function of internal $\mathrm{CO}_{2}$ partial pressure $[20,21]$ and includes the Ball et al. [5] empirical model of stomatal conductance. Model parameterization is described in detail in Harley and Tenhunen [28]. In the current study, an analytical solution for leaf net photosynthesis, for stomatal conductance, and for leaf internal and leaf surface $\mathrm{CO}_{2}$ concentration was used (Baldocchi 1994). Four basic equations were combined in a cubic equation for net photosynthesis (np, in $\mu \mathrm{mol} \mathrm{m} \mathrm{m}^{-2} \mathrm{~s}^{-2}$ ) which is solved according to the scheme of Bronstein and Semendjajew [11].

At low $\mathrm{CO}_{2}$ pressure and light saturation, $\mathrm{CO}_{2}$ fixation is limited by the potential rate of fixation by RubisCO $\left(w_{\mathrm{c}}\right)$, and at high $\mathrm{CO}_{2}$ pressure, by the potential rate of electron transport or the regeneration of ribulose1,5-bisphospate (RuBP) $\left(w_{\mathrm{j}}\right)$. Thus net photosynthesis $(n p)$ may be expressed as

$$
n p=\left(1-\frac{\Gamma^{*}}{c_{\mathrm{i}}}\right) \bullet \min \left\{w_{\mathrm{c}}, w_{\mathrm{j}}\right\}-0.5 \bullet r_{\mathrm{d}}
$$

where $0.5 \cdot r_{\mathrm{d}}$ is the dark respiration assumed to continue in the light (mmol m-2 s-1), $c_{\mathrm{i}}$ is leaf internal $\mathrm{CO}_{2}$ partial pressure and $\Gamma^{*}$ the $\mathrm{CO}_{2}$ compensation point in the absence of $r_{\mathrm{d}}$. Following Baldocchi [2], equation (A.1) is solved for $c_{\mathrm{i}}$ :

$$
c_{\mathrm{i}}=\frac{a \bullet d+b \bullet\left(n p+0.5 \bullet r_{\mathrm{d}}\right)}{a-e \bullet\left(n p+0.5 \bullet r_{\mathrm{d}}\right)} .
$$

If $w_{\mathrm{c}}<w_{\mathrm{j}}$, the coefficients $a, b, d$, and $e$ are replaced by $V c_{\max }$ (the maximum carboxylation volocity for the actual temperature), $K_{\mathrm{c}}\left(1+\mathrm{O}_{2} / \mathrm{Ko}\right)$ (considering oxygen concentration, and Michaelis-Menten constants for carboxylation and oxygenation), $\Gamma^{*}$, and 1 , respectively. If $w_{\mathrm{c}}>w_{\mathrm{j}}$, the coefficients $a, b, d$, and $e$ correspond to $4 P_{\mathrm{m}}$ (the maximum electron transport rate at actual light and temperature), $8 \Gamma^{*}, \Gamma^{*}$, and 4 .

Additional equations are needed to calculate leaf surface $\mathrm{CO}_{2}$ concentration $c_{\mathrm{s}}$, and leaf-internal $\mathrm{CO}_{2}$ concentration $c_{\mathrm{i}}$ assuming molecular diffusion in the boundary layer:

$$
\begin{aligned}
& c_{\mathrm{s}}=c_{\mathrm{a}}-\frac{1.6 \bullet \mathrm{np} \bullet 1000}{g_{\mathrm{a}}} \\
& c_{\mathrm{i}}=c_{\mathrm{s}}-\frac{1.6 \bullet \mathrm{np} \bullet 1000}{g_{\mathrm{s}}}
\end{aligned}
$$

where $c_{\mathrm{a}}$ is the $\mathrm{CO}_{2}$ concentration of the air. The factor 1000 derives from balancing the differing units used for $n p$ and the boundary layer conductance, $g_{\mathrm{a}}$, calculated as described below, or the stomatal conductance, $g_{\mathrm{s}}$, both in $\mathrm{mmol} \mathrm{m} \mathrm{m}^{-2} \mathrm{~s}^{-1}$. The factor 1.6 is the ratio of the diffusivities of water vapor and $\mathrm{CO}_{2}$ in air [19].

Laminar flow in the boundary layer, which would reduce the factor 1.6 in equation (A.3) to 1.3 , was neglected.

Stomatal conductance is calculated as:

$$
g_{\mathrm{s}}=g_{\text {min }}+\frac{g_{\mathrm{fac}} \bullet 1000 \bullet\left(n p+0.5 \bullet r_{\mathrm{d}}\right) \bullet h_{\mathrm{s}}}{c_{\mathrm{s}}}
$$

where $g_{\min }$ is the minimum conductance, $h_{\mathrm{s}}$ is relative humidity (as a decimal fraction), and $g_{\text {fac }}$ is an empirically determined constant. The factor 1000 adjusts for the different units of $g_{\mathrm{s}}$ and $\left(n p+0.5 r_{\mathrm{d}}\right)$.

For coniferous needles the calculation of $g_{\mathrm{a}}$ according to Nobel [44] was modified using so-called $\sigma$-factors of Jarvis et al. [31], for definition and measurements see Appendix 2). First, the thickness of the boundary layer $(d b l)$ is determined after Nobel [44], his equation (7):

$$
d b l=0.004 \cdot \sqrt{\frac{w}{u}}
$$

with $w$ the width of leaf (in $\mathrm{m}$ ), and $u$ the wind speed on the leaf surface (in $\mathrm{m} \mathrm{s}^{-1}$ ). The temperature dependence (temperature in ${ }^{\circ} \mathrm{C}$ ) of $d w v$, the coefficient of diffusivity 
for water vapor (in $\mathrm{m}^{2} \mathrm{~s}^{-1}$ ), is calculated according to Nobel [44], his Appendix 2:

$$
d w v=2.126 \cdot 10^{-5}+1.48 \bullet 10^{-7} \bullet T_{\mathrm{c}} .
$$

Calculation of the boundary layer conductance, $g_{\mathrm{a}}$ in mmol m${ }^{-2} \mathrm{~s}^{-1}$, (numerator as in Nobel [44], his Eqs. (8.3) and (8.8) denominator according to Jarvis et al. [31]) with consideration of the clumping of the needles on the branch gives:

$$
g_{\mathrm{a}}=\frac{\frac{d w v}{d b l} \bullet 1000 \bullet \frac{P}{R \bullet T_{\mathrm{k}}}}{1.67 \bullet \sigma^{0.43}}
$$

with $P$ pressure of the air (in $\mathrm{Pa}$ ), $T_{\mathrm{k}}$ leaf temperature (in $\mathrm{K})$ and $R$ the gas constant $\left(8.31 \mathrm{~J} \mathrm{~K}^{-1} \mathrm{~mol}^{-1}\right)$.

\section{Appendix 2}

\section{The definition and determination of $\sigma$-factors}

The $\sigma$-factors were used to estimate leaf boundary layer conductance (Eq. A.8), as well as to convert LAD (leaf area per volume crown section) for individual needles to the density for projected areas of intact twigs, e.g., the effective leaf area for light interception:

$$
\sigma=\frac{A_{\mathrm{n}}+A_{\mathrm{t}}}{A_{\mathrm{s}}}
$$

where $A_{\mathrm{n}}$ is the projected area of all needles laid out separately, $A_{\mathrm{t}}$ is the projected area of the twig, and $A_{\mathrm{s}}$ the projected area of the intact twig. Measurements of $A_{\mathrm{s}}, A_{\mathrm{t}}$ and $A_{\mathrm{n}}$ were obtained with a Delta-T Image Analysis System (Delta-T Devices LTD, Cambridge, England). For the determination of the $\sigma$-factors for each meter section of the harvested tree, three 2 nd or 3 rd order twigs were randomly selected. The $\sigma$-factors reflect the morphological light acclimation, and decrease with depth in the canopy (data not shown).

\section{REFERENCES}

[1] Alsheimer M., Köstner B., Falge E.M., Tenhunen J.D., Temporal and spatial variation in transpiration of Norway spruce stands within a forested catchment of the Fichtelgebirge, Germany, Ann. Sci. For. 55 (1998) 103-123.

[2] Baldocchi D.D., An analytical solution for coupled leaf photosynthesis and stomatal conductance models, Tree Physiol. 14 (1994) 1069-1079.
[3] Baldocchi D.D., Flux footprints within and over forest canopies, Boundary Layer Meteorol. 85 (1997) 273-292.

[4] Baldocchi D.D., Valentini R., Running S., Oechel W., Dahlman R., Strategies for measuring and modelling carbon dioxide and water vapour fluxes over terrestrial ecosystems, Global Change Biol. 3 (1996) 159-168.

[5] Ball J.T., Woodrow I.E., Berry J.A., A model predicting stomatal conductance and its contribution to the control of photosynthesis under different environmental conditions, in: Binggins I.J. (Ed.), Progress in photosynthesis research, Vol. IV.5, Martinus Nijhoff, Dordrecht, Netherlands, 1987, pp. 221-224.

[6] Bauerle W.L., Hinckley T.M., Cermák J., Kucera J., Bible K., The canopy water relations of old-growth Douglas-fir trees, Trees 13 (1999) 211-217.

[7] Bell A.D., Dynamic morphology: a contribution to plant population ecology, in: Dirzo R., Sarukhan J. (Eds.), Perspectives on Plant Population Ecology, Sunderland, Mass: Sinauer, 1984, pp. 48-65.

[8] Beyschlag W., Ryel R.J., Dietsch C., Shedding of older needle age classes does not necessarily reduce photosynthetic primary production of Norway Spruce. Analysis with a 3dimensional canopy photosynthesis model, Trees 9 (1995) 5159.

[9] Biron P., Le cycle de l'eau en forêt de moyenne montagne: Flux de sève et bilans hydriques stationnels (Bassin versant du Strengbach à Aubure-Hautes Vosges), Ph.D. Thesis, Louis Pasteur Université, Strasbourg, France, 1994.

[10] Björkman O., Comparative studies on photosynthesis in higher plants, Ann. Rev. Plant Physiol. 31 (1973) 491-543.

[11] Bronstein I.N., Semendjajew K.A., Taschenbuch der Mathematik, 21./22. Aufl., Harri Deutsch, Thun und Frankfurt/Main, Germany, 1987.

[12] Brooks J.R., Hinckley T.M., Ford E.D., Sprugel D.G., Foliage dark respiration in Abies amabilis (Dougl.) Forbes: variation within the canopy, Tree Physiol. 9 (1991) 325-338.

[13] Buchmann N., Hinckley T.M., Ehleringer J.R., Carbon isotope dynamics in Abies amabilis stands in the Cascades, Can. J. For. Res. 28 (1998) 808-819.

[14] Cermák J., Deml M., Penka M., A new method of sapflow determination in trees, Biol. Plant. (Praha) 15 (1973) 171-178.

[15] Cermák J., Kucera J., Penka, M., Improvement of the method of sapflow determination in full-grown trees based on heat balance with direct electric heating of xylem, Biol. Plant. (Praha) 18 (1976) 105-110.

[16] Cienciala E., Kucera J., Ryan M.G., Lindroth A., Water flux in boreal forest during two hydrologically contrasting years; species specific regulation of canopy conductance and transpiration, Ann. Sci. For. 55 (1998) 47-61.

[17] Falge E.M., Graber W., Siegwolf R., Tenhunen J.D., A model of the gas exchange response of Picea abies to habitat conditions, Trees 10 (1996) 277-287.

[18] Falge E.M., Ryel R.J., Alsheimer M., Tenhunen J.D., Effects of stand structure and physiology on forest gas 
exchange: A simulation study for Norway spruce, Trees 11 (1997) 436-448.

[19] Farquhar G.D., Sharkey, T.D., Stomatal conductance and photosynthesis, Ann. Rev. Plant Physiol. 33 (1982) 317342.

[20] Farquhar G.D., Von Caemmerer S., Modelling of photosynthetic response to environment, in: Lange O.L., Nobel P.S., Osmond C.B., Ziegler H. (Eds.), Encyclopedia of Plant Physiology, Vol. 12B, Physiological Plant Ecology II, Water Relations and Carbon Assimilation. Springer-Verlag, Berlin, 1982, pp. 549-587.

[21] Farquhar G.D., Von Caemmerer S., Berry, J.A., A biochemical model of photosynthetic $\mathrm{CO}_{2}$ assimilation in leaves of $\mathrm{C}_{3}$ species, Planta 149 (1980) 78-90.

[22] Goulden M.L., Munger J.W., Fan S.-M., Daube B.C., Wofsy S.C., Measurements of carbon sequestration by longterm eddy covariance: methods and a critical evaluation of accuracy, Global Change Biol. 3 (1996) 169-182.

[23] Granier A., Une nouvelle méthode pour la mesure du flux de sève brute dans le tronc des arbres, Ann. Sci. For. 42 (1985) 81-88.

[24] Granier A., Evaluation of transpiration in a Douglas-fir stand by means of sapflow measurements, Tree Physiol. 3 (1987) 309-320.

[25] Gross K., Pham-Nguyen T., Einfluß von langfristigem konstanten Wassermangelstreß auf die Nettophotosynthese und das Wachstum junger Fichten (Picea abies [L.] Karst.) und Douglasien (Pseudotsuga menziesii [Mirb.] Franco) im Freiland. Forstwiss. Cbl. 106 (1987) 7-26.

[26] Habermehl A., Hüttermann A., Lovas G., Ridder H.W., Computer Tomographie von Bäumen, Biologie in unserer Zeit 4 (1990) 193-200.

[27] Habermehl A., Ridder H.-W., Anwendungen der mobilen Computer-Tomographie zur zerstörungsfreien Untersuchung des Holzkörpers von stehenden Bäumen, Holz Roh- Werkstoff 51 (1993) 1-6.

[28] Harley P.C., Tenhunen J.D., Modeling the photosynthetic response of $\mathrm{C}_{3}$ leaves to environmental factors, in: Boote K.J., Loomis R.S. (Eds.) Modeling Crop Photosynthesis - from Biochemistry to Canopy, ASA, Madison, Wisconsin, 1991, pp. 17-39.

[29] Hinckley T.M., Sprugel D.G., Brooks J.R., Brown K.J., Martin T.A., Roberts D.A., Schaap W., Wang D., Scaling and integration in trees, in: Peterson D.L., Parker V.T. (Eds.), Ecological scale: theory and applications, Columbia University Press, New York, 1998, pp. 309-337.

[30] Hubbard R.M., Bond B.J., Ryan M., Evidence that hydraulic conductance limits photosynthesis in old Pinus ponderosa trees, Tree Physiol. 19 (1999) 165-172.

[31] Jarvis P.G., James G.B., Landsberg J.J., Coniferous forest. in: Monteith J.L. (Ed.), Vegetation and Atmosphere, Vol. 2, Case studies, Academic Press, London, 1976, pp. 171240.

[32] Joss U., Graber W., Profiles and simulated exchange of $\mathrm{H}_{2} \mathrm{O}, \mathrm{O}_{3}, \mathrm{NO}_{2}$ between the atmosphere and the HartX Scots pine plantation, Theor. App. Clim. 53 (1996) 157-172.
[33] Kelliher F.M., Leuning R., Schulze E.-D., Evaporation and canopy characteristics of coniferous forests and grasslands, Oecologia 95 (1993) 153-163.

[34] Köstner B., Schulze E.-D., Kelliher F.M., Hollinger D.Y., Byers J.N., Hunt J.E., McSeveny T.M., Mesert R., Weir P.L., Transpiration and canopy conductance in a pristine broadleaved forest of Nothofagus: an analysis of xylem sap flow and eddy correlation measurements, Oecologia 91 (1992) 350-359.

[35] Köstner B., Biron P., Siegwolf R., Granier A., Estimates of water vapor flux and canopy conductance of Scots pine at the tree level utilizing different sap flow methods, Theor. Appl. Clim. 53 (1996) 105-114.

[36] Köstner B., Alsheimer M., Falge E.M., Geyer R., Tenhunen J.D., Relationships between canopy transpiration, conductance, and tree capacitance of an old Norway spruce (Picea abies) stand, Ann. Sci. For. 55 (1998) 125-139.

[37] Kucera J., Cermák J., Penka M., Improved thermal method of continual recording the transpiration flow rate dynamics, Biol. Plant. (Praha) 19 (1977) 413-420.

[38] Kull O., Koppel A., Net photosynthetic response to light intensity of shoots from different crown positions and age in Picea abies [L.] Karst., Scand. J. For. Res. 2 (1987) 157166.

[39] Lange O.L., Weikert R.M., Wedler M., Gebel J., Heber U., Photosynthese und Nährstoffversorgung von Fichten aus einem Waldschadensgebiet auf basenarmeme Untergrund, Allg. Forst Zeitschr. 3 (1989) 55-64.

[40] Lu P., Biron P., Bréda N., Granier A., Water relations of adult Norway spruce (Picea abies [L.] Karst.) under soil drought in the Vosges mountains: water potential, stomatal conductance and transpiration, Ann. Sci. For. 52 (1995) 117129.

[41] Martin T.A., Brown K.J., Cermák J., Ceulemans R., Kucera J., Meinzer F.C., Rambold J.S., Sprugel D.G., Hinckley T.M., Crown conductance and tree and stand transpiration in a second-growth Abies amabilis forest, Can. J. For. Res. 27 (1997) 797-808.

[42] Mirschkorsch C., Die Stamm- und Zweigrespiration eines jungen Fichtenbestandes (Picea abies [L.] Karst.) und die Bedeutung für den $\mathrm{CO}_{2}$-Netto-Austausch, Diploma thesis, University of Bayreuth, Bayreuth, Germany, 1996.

[43] Monteith J.L., Vegetation and the Atmosphere, Vol. 2, Academic Press, New York, 1976.

[44] Nobel P.S., Biophysical Plant Physiology and Ecology, W.H. Freeman and Company, San Francisco, 1983.

[45] Norman J.M., Radiation transfer in vegetation, in: de Vries D.A., Afgan N.H. (Eds.), Heat and Mass Transfer in the Biosphere, Scripta Book Co, Washington DC, 1975.

[46] Norman J.M., Interfacing leaf and canopy light interception models, in: Hesketh J.D., Jones J.W. (Eds.), Predicting Photosynthesis for Ecosystem Models, CRC Press Inc, Boca Raton, Florida, 1980.

[47] Öquist G., Brunes L., Hällgren J.-E., Gezelius K., Hallén M., Malmberg G., Effects of artificial frost hardening and winter stress on net photosynthesis, photosynthetic electron 
transport and RuBP carboxylase activity in seedlings of Pinus sylvestris, Physiol. Plant. 48 (1980) 526-531.

[48] Oren R., Phillips N., Ewers B.E., Pataki D.E., Megonigal J.P., Sap-flux-scaled transpiration responses to light, vapor pressure deficit, and leaf area reduction in a flooded Taxodium distichum forest, Tree Physiol. 19 (1997) 337347.

[49] Pereira J.S., Tenhunen J.D., Lange O.L., Beyschlag W., Meyer A., David M.M., Seasonal and diurnal patterns in leaf gas exchange of Eucalyptus globulus trees growing in Portugal, Can. J. For. Res. 16 (1985) 177-184.

[50] Phillips N., Nagchaudhuri A., Oren R., Katul G., Time constant for water transport in loblolly pine trees estimated from time series of evaporative demand and stem sapflow, Trees 11 (1997) 412-419.

[51] Pollard D.F.W., Logan K.T., The effect of light intensity, photoperiod, soil moisture potential, and temperature on bud morphogenesis in Picea species, Can. J. For. Res. 7 (1977) 415-421.

[52] Pretzsch H., Growth trends of forests in Germany, in: Spiecker H., Mielokäinen K., Köhl M., Skovsgaard J.P. (Eds.), Growth trends in European forests, Springer Verlag, Heidelberg, 1996, pp. 107-131.

[53] Roberts J., Forest transpiration: a conservative hydrological process?, J. Hydrol. 66 (1983) 133-141.

[54] Ross J., Radiative transfer in plant communities, in: Monteith J.L. (Ed.), Vegetation and the Atmosphere, Vol. 1, Academic Press, New York, 1975.

[55] Ryan M.G., Yoder B.J., Hydraulic limits to tree height and tree growth, BioScience 47 (1997) 235-242.

[56] Ryan M.G., Binkley D., Fownes J.H., Age-related decline in forest productivity: pattern and process, Advances in Ecological Research 27 (1997) 213-262.

[57] Ryel R.J., Light relations in tussock grasses as assessed with a new three-dimensional canopy photosynthesis model. Structure and function of foliage organization of a growth form prevalent in environments characterized by stress, Ph.D. Thesis, University of Würzburg, Würzburg, Germany, 1993.
[58] Ryel R.J., Beyschlag W., Caldwell M.M., 1993, Foliage orientation and carbon gain in two tussock grasses as assessed with a new whole-plant gas exchange model, Func. Ecol. 7 (1993) 115-124.

[59] Sala A., Tenhunen J.D., Simulations of canopy net photosynthesis and transpiration in Quercus ilex L. under the influence of seasonal drought, Agric. For. Meteorol. 78 (1996) 203-222.

[60] Schäfer K.V.R., Oren R., Tenhunen J.D., The effect of tree height on sap flux-scaled canopy stomatal conductance in Fagus sylvatica L. Submitted to Plant, Cell and Environ. 1999.

[61] Schmid H.P., Source areas for scalars and scalar fluxes, Boundary Layer Meteorol. 67 (1994) 293-318.

[62] Schulze E.-D., Cermák J., Matyssek R., Penka M., Zimmermann R., Vasicek F., Gries W., Kucera J., Canopy transpiration and water fluxes in the xylem of the trunk of Larix and Picea trees - comparison of xylem flow, porometer and cuvette measurements, Oecologia 66 (1985) 475-483.

[63] Schulze E.-D., Lange O.L., Oren R., Forest decline and air pollution. A study of spruce (Picea abies) on acid soils. Ecological Studies Vol. 77, Springer Verlag, Berlin Heidelberg New York, 1989, pp. 475.

[64] Tenhunen J.D., Valentini R., Köstner B., Zimmermann R., Granier A., Variation in forest gas exchange at landscape to continental scales, Ann. Sci. For. 55 (1998) 1-11.

[65] Tenhunen J.D., Ryel R.J., Joss U., Falge E., Geyer R., Penumbral and foliage distribution effects on Pinus sylvestris canopy water use and gross primary production, Theor. Appl. Climatol. 1999, in press.

[66] Williams M., Rastetter E.B., Fernandes D.N., Goulden M.L., Wofsy S.C., Shaver G.R., Melillo J.M., Munger J.W., Fan S.-M., Nadelhoffer K.J., Modelling the soil-plant-atmosphere continuum in a Quercus-Acer stand at Harvard Forest: the regulation of stomatal conductance by light, nitrogen and soil/plant hydraulic properties, Plant Cell Environ. 19 (1996) 911-927.

[67] Yoder B.J., Ryan M.G., Waring R.H., Schoettle A.W., Kaufmann M.R., Evidence of reduced photosynthetic rates in old trees, For. Sci. 40 (1994) 513-527. 